\title{
SISTEMAS DE CULTIVOS, AMBIENTE E SAÚDE
}

\section{LOS SISTEMAS DE CULTIVOS, EL MEDIO AMBENTE Y LA SALUD}

\section{SYSTEMS OF CULTIVATIONS, ENVIRONMENT AND HEALTH}

\author{
Isaura Isabel CONTE ${ }^{1}$ \\ Franciéli Aline CONTE ${ }^{2}$
}

RESUMO: Este texto aborda os sistemas de produção convencional, transgênico, agroecológico e orgânico, apresentando diferenças entre um e outro, e, para tanto, parte-se de estudos teóricos e de acompanhamento de debates feitos pela Via Campesina/(Rio Grande do Sul, Brasil) nos últimos três anos. Questiona-se sobre o uso dos transgênicos e também da chamada produção convencional à base de agrotóxicos e químicos industriais, fazendo relação com os aspectos nutricionais dos alimentos produzidos e alguns impactos sobre o ambiente. Outra abordagem é relacionada com a falta de políticas para a agroecologia no Brasil ao longo dos tempos, o descumprimento das leis e a não fiscalização sobre os agrotóxicos e os transgênicos deixando a população desassistida e com poucas possibilidades de enfrentar a situação tanto no campo quanto na cidade. Considera-se que a efetivação das políticas (recentes) para a agroecologia é um enorme desafio no Brasil e implica em ir negando e substituindo o chamado modelo convencional de produção para possibilitar maior escala de produção e disponibilização de alimentos saudáveis para as populações em geral.

Palavras-chave: sistemas de produção; alimentos; ambiente; agrotóxicos; saúde.

RESUMEN: El presente trabajo aborda los sistemas de producción convencional, transgénico, agroecológico y orgánico, presentando diferencias entre ellos, y, a su vez, parte de los estudios teóricos y de seguimiento de discusiones realizadas por la Vía Campesina / ( Rio Grande do Sul, Brasil) en los últimos tres años. Se pregunta sobre el uso de OMG y también la llamada producción convencional basada en plaguicidas y productos químicos industriales, haciendo la relación con los aspectos nutricionales de los alimentos y algunos de los impactos sobre el medio ambiente. Otro enfoque se relaciona con la falta de políticas a la agroecología en Brasil a través del tiempo, el incumplimiento normativo y sin supervisión de los pesticidas y transgénicos, poniendo la población marginada, con pocas posibilidades para hacer frente a la situación, en el campo y en la ciudad. Se considera que la realización de las políticas (recientes) de la

${ }^{1}$ Doutoranda em Educação pela UFRGS, Mestra em Educação nas ciências pela Universidade Regional do Noroeste do Rio Grande do Sul (UNIJUI). isauraconte@yahoo.com.br

${ }^{2}$ Graduanda em Nutrição pela UNIJUI. francieliconte@ yahoo.com.br 
agroecología es un gran desafío en Brasil e implica negar ir y reemplazar el llamado modelo de producción convencional para permitir una mayor escala de producción y disponibilidad de alimentos saludables para la población en general.

Palabras clave: sistemas de producción; alimentos; medio ambiente; plaguicidas; la salud.

\begin{abstract}
This text approach the conventional, transgenic, agroecological, and organic systems of production, presenting the difference between them, for this part of the theoretical studies and discussions has been made Via Campesina/(Rio Grande do Sul, Brazil) in the last three years. Questioning about the use of transgenic and also the conventional production based on pesticides and industrial chemicals, making relationship with the nutritional aspects of produced foods and some impacts on the environment. Another approach is related with the lack of policies to agroecology in Brazil, over time the noncompliance of the laws and the lack of supervision about agrochemicals and transgenic are leaving the unassisted population with few possibilities to face the situation in the field and in the city. It is considered that the realization of (recent) policies for agroecology is a huge challenge in Brazil and involves denying goes and replacing the so-called conventional production model to enable larger scale production and delivery of healthy food to the population in general.
\end{abstract}

Keywords: production systems; food; environment; pesticides; health.

\title{
INTRODUÇÃO
}

Por meio deste texto, pretendemos discutir as formas de cultivos evidenciando diferenças entre o convencional, transgênico, orgânico e agroecológico, bem como algumas consequências no ambiente e na saúde das pessoas, embora nesse último campo, haja uma enorme dificuldade de comprovação quando se trata do efeito dos agrotóxicos. De uma maneira, ocorre devido á falta de realização de pesquisas, ou, de as pesquisas existentes serem vinculadas a grandes corporações com seus laboratórios, que afinal, as financiam e, desse modo Andrioli e Fuchs (2008) questionam sua veracidade. Além disso, os laudos médicos são pouco precisos quando se trata de contaminação ou mesmo de morte causadas por agrotóxicos e a dificuldade aumenta ainda mais quando é o caso de exposição à longo prazo com efeito cumulativo.

Uma questão colocada à sociedade é da necessidade de um volume grande de alimentos para a população existente no planeta e, diante disso nos deparamos com um grande dilema: se há fome, há de se produzir mais e, assim, foi feita a defesa de uma agricultura baseada em um sistema químico dependente, chamado de convencional, e daí o surgimento da utilização dos agrotóxicos. A pergunta que vem logo em seguida é: como fica a saúde das pessoas? Haveria 
outra maneira de produzir mais sem agrotóxicos e outros químicos? E o ambiente? Mas, essas perguntas não eram ouvidas, ou não havia espaço para serem feitas em alta voz quando se optou em tornar a agricultura "produtiva", como se não fora anteriormente: leia-se anterior à década de 1960 na América Latina. Partindo dessas pontuações iniciais, destacamos que vamos tratar do caso específico do Brasil e, assim sublinhamos que a primeira Lei, ou melhor, Decreto considerando oficialmente a produção orgânica no país é posta a público no ano de 2003, sob o número 10.831, embora houvesse iniciativas isoladas em favor dos orgânicos ou agroecológicos. Entre a escassez e o grande volume de alimentos necessários, analisando o passado, apontamos ainda outros questionamentos: se o Brasil historicamente tem sido um país monocultor e exportador de matérias- primas, quem produzia a comida do povo trabalhador nas fazendas e nas minas? Quem produzia e como produziam os alimentos que sustentavam casas grandes e senzalas? Maria Isaura de Queiroz (2009) diria que as plantações de tudo o que era diversificado ficava escondida atrás das casas grandes, sendo considerada de segunda ordem, uma agricultura dos pobres, sem reconhecimento. Otávio Guilherme Velho (1979) responderia que por detrás dos grandes plantations de cana de açúcar, café, etc., havia um tipo de agricultura subordinada. Contudo, o que estamos querendo dizer parece óbvio: para além de leis e decretos, muito recentes por sinal, sobre a produção orgânica, a agroecologia sempre existiu e fora largamente praticada, pelos indígenas, pelos negros e negras aquilombados e todos os seus descendentes; mais tarde também pelos imigrantes trabalhadores em regime de colonato ou na agricultura familiar/camponesa, ao menos até os idos dos anos de 1960.

Demais questões que instigam esse texto é: porque vieram os transgênicos se disseram que a revolução verde iria acabar como a fome no planeta? Ela não fez produzir muito mais? a resposta é sim, com certeza, mas... essa produção mais que do nunca veio a ser direcionada a grandes empresas, laboratórios de pesquisa, corporações financeiras, ao passo que, um enorme contingente de agricultores e agricultoras, considerados menos modernos, eram "levados", ou melhor, expulsos do campo pelo chamado êxodo rural. Além disso, uma enorme quantidade de posseiros, sem título de terra registrada, em sua maioria descendentes de indígenas e negros, estava sempre em fuga dos projetos de ocupação de suas terras, mato à dentro, como diria Maestri (2000), até que havia mato...

Assim, nos deparamos nos dias atuais com a seguinte situação: a falta de reforma agrária para um país que concentrou terra e riqueza para poucos desde o início da invasão portuguesa, conjugado 
com sistemas de produção que ia consumindo as riquezas do país e enriquecendo Portugal e outros países da Europa segundo Galeano (1991). Nessa harmonia de concentração e sistema produtivo oficializado com o aval de reis de Portugal, de imperadores e, por último na chamada República, ocorriam ao revés as desarmonias: de populações que se negavam a produzir dentro dos moldes estabelecidos e, propriamente a trabalhar como peões; povos que não se fixavam num local somente e praticavam agricultura conforme seus ancestrais, contando com o extrativismo.

Logo, o que se chama de sistema convencional de produção, atualmente oriundo da revolução verde, não era o que vigorava ao longo dos tempos, pois o sistema químico-industrial, segundo Pollan (2007) teve início na década de 1930 e mais tarde se expandiu pelo mundo. A produção de alimentos, que abastecia as populações vinha de lugares onde não se queria e ainda há poucas evidências para enxergar: dos roçadinhos, da pequena roça, e, inclusive, do trabalho feminino sem dúvida. Sobre essa questão, Melo e Di Sabbato (2009) descrevem a partir do censo agropecuário de 2006 , que cerca de $80 \%$ do trabalho das mulheres na agricultura é trabalho sem remuneração, em grande parte, dispendido na produção e preparo de alimentos.

Não obstante, dados do MDA (2009), demonstram que mais de $70 \%$ da alimentação consumida no Brasil, provém das pequenas unidades de produção, ou seja; da agricultura familiar/camponesa, ainda que esta, na atualidade, produz em grande medida na maneira chamada de convencional, pois são ainda raros os incentivos para a produção agroecológica. Segundo Rubio (2001), com a liberalização dos mercados no neoliberalismo da década de 1990 em diante, a industrialização da agricultura passou a ser comandada por corporações internacionais, sendo que o agronegócio vai parecer com força nos anos 2000, sufocando ainda mais a chamada pequena agricultura produtora de alimentos diversificados.

\section{Sistemas Produtivos Atuais e Algumas Consequências para o Ambiente e a Saúde}

Conforme aponta a introdução desse texto, os sistemas de cultivos tem a ver com as políticas que o país desenvolve em vista de alavanca-los ou negá-los como se não existissem, ou mesmo, deixar na invisibilidade quando não é tido como um "carro-chefe" de uma determinada política governamental ou estatal. Assim o modo de produção que sempre fora convencional, aquele praticado por povos ao longo dos tempos e civilizações, inclusive contando com técnicas avançadas, na atualidade não é visto, ou, é pouco notado. Ou, ainda, nesse momento de crise ambiental planetária, tem-se feito notar e, por isso, fala-se mais do que em outros tempos em 
agroecologia e produção orgânica, considerando que a primeira é muito mais ampla do que a produção de alimentos saudáveis em si; é tida como ciência e modo de vida para além da produção, visto que inclui um modelo de agricultura menos agressivo ao meio ambiente, além de promover a inclusão social e proporcionar melhores condições econômicas aos agricultores (CAPORAL e COSTABEBER, 2004).

A produção agroecológica é diferenciada daquela considerada orgânica em algum sentido, salientando uma perspectiva política abrangente, bem mais do que as políticas públicas propriamente ditas, pois até o ano de 2012, de parte do governo era tratado do sistema de orgânicos e não agroecológicos. A lei que vai considerar a agroecologia junto aos orgânicos (como sendo sinônimos um do outro, embora de fato não sejam) é a Política Nacional de Agroecologia e Produção Orgânica (PNAPO, 2012), contudo, ambas são tidas ou consideradas ecológicas. Pode-se afirmar que os dois sistemas estão numa mesma direção, mas a agroecologia, conforme já salientado, é mais abrangente e divergem com a maneira de produção considerada convencional baseada no uso de agrotóxicos e demais insumos químicos. São mais conflitantes e incompatíveis ainda com os transgênicos, tratados como organismos geneticamente modificados (OGM's), largamente disseminados no Brasil a partir do ano 2000 à revelia da legislação ambiental em vigor naquele período.

A agroecologia tem recebido destaque nos últimas décadas, especialmente nos últimos 15 anos no Brasil devido aos benefícios gerados com relação à natureza e à saúde humana e, de acordo com Costa (2008), Ana Primavesi no Brasil, foi uma das precursoras da defesa desse modo de produção e vida, apontando já no final da década de 70, os desastres ocasionados pela revolução verde incorporados na maneira de produção chamada de convencional. De acordo com Lima e Souza (2011), na agroecologia não se trabalha com agrotóxicos ou mesmo com produtos químicos industrializados, evitando contaminações de rios, veias d'água, plantações vizinhas, solos, alimentos, ar, animais e pessoas. Devido a estes fatores é considerada um modelo de produção saudável, e, nesse momento muito em voga por causa das consequências do desenvolvimento econômico a qualquer custo.

A diferenciação entre as formas de cultivo agroecológico e orgânico tem sido feita nos últimos anos, devido a existência de setores sociais organizados, com destaque a Movimentos populares do campo e ONG's ambientalistas no mundo todo, os quais não aceitaram a tolerância da alteração nas legislações vigentes, em que foi sendo possível considerar produto orgânico aqueles 
que podem receber uma certa quantidade de agroquímico permitido por Lei. Nesse sentido, o Decreto dos orgânicos de número 10. 831/2003 deixa algumas lacunas e assim, setores da economia baseada em larga produção considerada orgânica, pressiona para a lei tolerar certas medidas que lhes favoreçam. Grosso modo, os orgânicos são associados a um modelo rentável com padrões de certificação, podendo ser em grande escala, ao passo que, os defensores da agroecologia são acusados de esquerdistas, negando em grande parte as burocracias exigidas na certificação dos produtos.

Uma das articulações bastante ampla, de incentivo ao cultivo e comercialização de produtos agroecológicos que entrou com força nestes debates foi a Rede Ecovida, preferindo então, utilizar o termo (agro)ecológico ao invés de orgânico, pois os produtos considerados agroecológicos são aqueles em que não há nenhum componente químico industrial na adubação do solo, tampouco podem receber tratamentos da mesma natureza. Os fertilizantes e repelentes de insetos são todos oriundos de decomposição e manipulação de material disponibilizado pela natureza (REDE ECOVIDA, 2012). Outros debates consistentes acerca desse tema são feitos na Associação Brasileira de Agroecologia (ABA) e, por sua vez na Articulação Nacional de Agroecologia (ANA) criadas entre os anos 2002 e 2004, nas quais há representação dos movimentos da Via Campesina/Brasil (ABA, 2014).

Na comparação dos regimes de produção agroecológico e orgânico, pode-se afirmar que a diferença entre ambas está na concepção das relações de produção e distribuição bem mais do que na maneira de produção. Para esclarecer: de acordo com Pollan (2007), na União Europeia e EUA há um mercado grandioso de orgânicos, inclusive é possível a produção em grande escala, sendo a distribuição para grandes redes de supermercados, não importando quem pode adquirir esses produtos, em grande parte produzida com mão de obra explorada de latinos, mexicanos, africanos, etc. No caso da produção agroecológica, prima-se por sustentar a produção nos moldes da agricultura camponesa/familiar, estabelecendo redes do chamado comércio justo, pois, defende-se a ideia de quem produz agroecológico dever usufruir dessa produção, assim como as classes populares. Esse debate é processado em setores vinculados à Via Campesina e, no Brasil, força-se em políticas públicas como as compras institucionais do Programa de Aquisição de Alimentos (PAA) e Programa Nacional de Alimentação Escolar (CONTE, 2013).

A produção considerada convencional é aquela oriunda da revolução verde, vinculada a maior produtividade possível, por isso, é à base de agrotóxicos e demais insumos químicos que 
estimulam produzir mais em menos tempo. Esta "revolução agrícola" foi largamente difundida nos países da América Latina em nome de acabar com a fome no mundo. Na afirmação de Conway (2003, p. 56) "fome e pobreza podem ser eliminadas pela aplicação da ciência e da tecnologia modernas, contanto que elas sejam utilizadas em larga escala e sejam sustentadas por políticas econômicas e sociais apropriadas". Contudo, diante desta "Revolução" não se pensava nas consequências, especialmente para o ambiente, com a utilização do pacote sobrado da segunda guerra mundial que foi destinado à agricultura na América Latina de forma especial.

Nesse sentido, estimulou-se esse sistema no Brasil, principalmente nos governos ditatoriais (1964 a 1985) em nome do desenvolvimento, entendido como crescimento econômico e assim o país passou a ser um dos maiores exportadores de soja do mundo em poucos anos, incluindo também a pequena agricultura. Os planos e políticas eram direcionados a derrubar mato e fazer lavouras em todos os lugares possíveis sob o slogan "plante que o governo garante". De acordo com Guanziroli e Berenger (2010), na década de 70 se deu, por incentivo estatal as grandes aberturas de fronteira agrícola na Amazônia e Cerrado brasileiro, inclusive houve a criação da Embrapa Soja para adaptar espécies a esses biomas.

Esse modelo de produção foi chamado de convencional e necessitava sempre de mais e mais terras produtivas, alargando as extensões (expulsando e matando populações), mas ainda assim entra em crise no final da década de 1980 (RUBIO, 2001) e, assim, como uma sequência desse modelo surge algo mais inovador, com maior tecnologia: os transgênicos. Eles surgem no cenário brasileiro, junto a uma enorme polêmica, pois antes mesmo de serem testados e liberados, já estavam sendo cultivados. Desse modo, os Movimentos populares do campo, especialmente aqueles ligados à Via Campesina, debateram o assunto, mas acabaram perdendo na força política frente ao agronegócio e o apoio do então governo Lula e houve a sua liberação oficial.

Intensificou-se junto à população o convencimento de que seria possível produzir ainda mais, com menor custo e em menos espaço territorial, também com menor quantidade de agrotóxicos, o que se constata neste momento ser uma grande farsa, de acordo com Andrioli e Fuchs (2008). No sistema de produção transgênica, cujos genes das plantas são modificados geneticamente e até misturados com outros (seja planta, fungo ou de origem animal), os alimentos são transformados em commodities, ou seja, mercadorias que, mais que sua função de alimentar pessoas, ficam subordinados ao sabor dos ventos das bolsas de valores no mercado especulativo. 
Ao compararmos o modelo de produção agroecológico com o convencional percebemos a primeira e grande diferença entre ambos, pois, na segunda é intenso o uso de agrotóxicos ou mesmo de químicos como o nitrato, o qual pode ser altamente prejudicial ao ser humano quando consumido por meio do consumo de plantas que recebem estas substâncias. Nos alimentos orgânicos in natura, por sua vez, é perceptível aspectos como, tamanho um pouco menor pelo fato de não serem forçados, mas com maior sabor, odor e coloração (LEAL et al.,2007).

Em se tratando de alimentos, na comparação dos convencionais e transgênicos, com os orgânicos e agroecológicos entra em questão o valor nutricional. Além da arena política da defesa de modelos ou sistemas diferentes e até antagônicos de se fazer e se investir na agricultura, há discussões acerca da mudança cultural e de hábitos alimentares e o que isso tem interferido na saúde das pessoas. Mais do que fazer uma discussão sobre a questão alimentar e nutricional, segundo as diferentes perspectivas dos sistemas de produção abordados anteriormente, estamos tratando de questões referentes ao ambiente e, porque não, da própria continuidade do planeta. Para tanto, não podemos omitir que se trata de questões políticas e, acima de tudo, financeiras. Poderíamos perguntar: está-se produzindo, commoditie, alimento ou comida? Quem tem acesso a um ou a outro? Desde uma perspectiva, se fala em um bilhão de pessoas famintas no planeta, segundo dados da FAO e, de outra, é grande a propaganda sobre as super-safras e a abundância de alimentos. O que está acontecendo afinal?

Pesquisa desenvolvida no Vale do Taquari (RS), por Menache, Marques e Zanetti (2008), aponta que a segurança dos alimentos está no fato de serem saudáveis, e segundo os agricultores eles estão na comunidade e não no mercado. Então, para os produtores, estes são dignos de confiança e prestígio, pois se conhece a procedência. As pessoas pesquisadas afirmam que os alimentos são comida e isto quer dizer que são mais do que produtos, pois a comida tem a ver com a família, com o trabalho e as relações sociais, ou seja, com a cultura.

Em um sentido parecido, Maria José Carneiro (2009), ao estudar a mudança nos hábitos alimentares na região serrana do Rio de Janeiro, fala da rede se sociabilidade que se cria em torno dos alimentos, destacando que, por vezes, o valor social é maior que o valor econômico, garantindo coesão do tecido social entre as famílias da região. A autora também registra que, quem produz com agrotóxico, produz para venda e não para consumo próprio, o que não deixa de ser um problema do ponto de vista da sustentabilidade e do cuidado com a saúde das demais pessoas, envolvendo questões de ética; uma ética que não pode ser separada da política e da 
técnica conforme insistia Paulo Freire (1987). De outra maneira, podemos afirmar que o papel do Estado tem sido negligente frente ao fornecimento de assistência técnica para fins de produção agroecológica e mesmo, orgânica, ficando a responsabilidade sobre as pessoas que trabalham produzindo os alimentos.

A produção chamada de convencional não surgiu por acaso, tampouco os transgênicos; eles provocaram uma verdadeira revolução na maneira de produzir, consumir e pensar das pessoas. A grande maioria das universidades, laboratórios, e mídias, de forma especial, cumpriram um papel importante para consolidar um sistema e um modo de vida, ao passo que, por ouro lado, foram colocando outros como atrasados e retrógrados (ABRASCO, 2012). Atualmente se chama de convencional a produção que inclui agrotóxicos, mesmo nos chamados "tratamentos", sendo as sementes híbridas, vinculadas a laboratórios com a respectiva de marca da empresa ou corporação do ramo. Por quê esta produção seria convencional e não aquela que historicamente fora feita pelos grupos humanos desde a antiguidade? Nesta última, as sementes não têm donos e donas, elas circulam nas comunidades a milhares de anos, foram e são selecionadas e melhoradas segundo os conhecimentos tradicionais e, jamais patenteadas.

Se por um lado o modo de produção convencional propiciou um avanço na produção de alimentos, por outro, veio a contribuir com a degradação ambiental, os grandes desmatamentos, a poluição dos rios, a resistência das plantas aos agrotóxicos necessitando de doses maiores e mais potentes. A revolução verde foi imposta, não somente para aumentar o volume de alimentos, já que as maiores produções sempre foram de milho, soja e trigo e para tanto, a maior parte destinase para a exportação, fabricação de rações e combustíveis (ANDRIOLI, FUCHS, 2008). De outro modo, há poucos espaços para questionar sobre os investimentos públicos, se, ao invés de serem feitos na maneira chamada de convencional fossem alocados para a agroecologia. Em nosso entendimento, se ela tivesse tais investimentos, não se trataria de nichos e produção em pouca escala, sem contar que a produção baseada em agrotóxicos e químicos industriais a impedem e a tornam inviável devido as condições de esgotamento e contaminação do solo, das águas, proliferação de insetos sem predadores naturais, ou mesmo a morte de insetos e outros organismos vivos, essenciais ao equilíbrio da fauna e flora.

Estudos de Ribeiro (2003, p. 57) apontam os transgênicos como ameaças concretas á vida do planeta como um todo, com consequências sérias aos humanos, pois, trata-se de contaminação biológica, com desestabilização de espécies ocasionando perdas das sementes cultivadas e 
melhoradas a milhares de anos. Inclusive, com o patenteamento das sementes em alguns casos está havendo a introdução do gene terminator, ou, exterminador, entendido como introdução de um gene suicida nas sementes, pois ela nasceria somente uma vez. Segundo a autora, está se produzindo uma "enorme contaminação genética e cultural, coadjuvando para expulsar os atores da biodiversidade das suas comunidades e do acesso aos recursos, incluída a área e o território". No texto, é tratado de espécies vegetais, mas podemos fazer a mesma relação com as espécies animais.

De acordo com Grisólia (2005), o aumento dos casos de cânceres, alergias, problemas hepáticos, distúrbios do sistema nervoso central e reprodutivo, são alguns dos problemas ocasionados á longo prazo pelo uso contínuo direto ou indireto dos agrotóxicos, sendo que estes podem estar associados aos alimentos pela ingestão, bem como através de inalações, ou via tópica ${ }^{2}$. Uma vez no organismo, os agrotóxicos não são degradados, e ao contrário, alojam-se em tecidos gordurosos, como podem estar na corrente sanguínea e inclusive no leite materno, conforme mostram pesquisas, amplamente divulgadas, realizadas sob responsabilidade do professor Wanderlei Pignati da UFMT ${ }^{2}$. Tais diagnósticos foram obtidos a partir de amostras coletadas em mulheres que vivem em regiões com larga plantação de soja e milho transgênicos no Estado do Mato Grosso.

No bojo desses problemas com a introdução da transgenia, surgem outros para os pequenos agricultores, como: a dependência das multinacionais para a compra dos agrotóxicos e das sementes que não germinam caso sejam guardadas para o replantio; ou, se germinam, não produzem; a resistência desenvolvida pelas ervas daninhas ao longo do uso contínuo e exacerbado dos agrotóxicos, antes, durante e depois do plantio; a morte de insetos e microrganismos benéficos para a flora e fauna; o pagamento de royaltys pelo uso da tecnologia, ou mesmo, o pagamento de multas pela contaminação decorrente dos ventos, insetos, transporte ou mistura de sementes durante o armazenamento. Diante de tudo, voltamos a indagar: que qualidade teriam os alimentos transgênicos? Que alternativa tem a população mais empobrecida em não consumi-la? Quais as informações que circulam nas mídias a respeito deles? O que sabe a população acerca disso?

\footnotetext{
${ }^{2}$ Absorção através da pele.

${ }^{2}$ Universidade Federal de Mato Grosso.
} 
Os transgênicos surgem nos Estados Unidos ano de 1983 e em 1996 tem uso permitido em países como Canadá e Argentina (FUCK e BONACELLI, 2009) e, com a liberação surgem os problemas ambientais e também o aumento da desigualdade social, pois, algumas poucas empresas e empresários aumentaram enormemente seus lucros, concentrado esta produção e também concentrando terras e demais recursos naturais para si. As sementes geneticamente modificadas são experimentadas/testadas em laboratórios, por ratos durante alguns dias ou no máximo semanas e, a partir daí, alcança uma enorme gama de alimentos que vão desde as oleaginosas, frutíferas, leguminosas até atingir animais como ovelhas, frangos, cabras, gado, coelhos, suínos, e peixes como salmão e robalo os quais podem crescer $25 \%$ acima de seu potencial normal (GUERRANTE, 2003, p. 25).

Segundo a mesma autora, os animais modificados geneticamente recebem uma alimentação altamente concentrada de hormônios para o crescimento, proporcionando engorda mais rápida, e consequente diminuição do tempo para o abate. De outra maneira, pouco se pensa na saúde de quem vai consumir este tipo de carne, tampouco, na qualidade de vida dos animais, que em geral, são confinados e pouco podem se movimentar. Evidentemente, o objetivo é alcançar maiores lucros com a transgenia, por parte das corporações que se apropriaram de tecnologias, muitas delas, desenvolvidas com recurso público e em Universidades ou Instituições Federais.

Esta "tecnologia" está envolvida diretamente com a atribuição de hormônios do crescimento e antibióticos na alimentação dos animais. Os animais que sofrem estas bruscas transformações passam por processos de estresse, alimentação exacerbada com a adição de produtos que permitem o aumento da sede e da própria fome em vista de crescimento rápido. É ainda percebido uma grande aglomeração que os fazem ficar mais sensíveis ao cortisol (hormônio do estresse) e ao aumento de calor, fazendo-os enfartarem muito facilmente. Uma das maiores preocupações acerca deste modo de produção é a resistência humana aos antibióticos e seus agravos à saúde devido ao consumo de alimentos à base destes "tratamentos" (MAGALHÃES, 1998).

Em cada país as legislações e decretos são diferentes com relação aos transgênicos, e, a exemplo do Brasil, o Decreto 4.680, de 24 de abril de 2003, estabelece que tanto os produtos embalados, como aqueles vendidos a granel ou in natura, que contenham ou sejam produzidos a partir de organismos geneticamente modificados, com presença acima do limite de $1 \%$ do produto, 
deverão ser rotulados (BRASIL, 2013). Esta é uma maneira de os consumidores e consumidoras serem informados sobre a espécie doadora do gene no local reservado para a identificação de ingredientes. Contudo, a grande maioria das pessoas desconhecem as nomenclaturas e termos científicos utilizados para esta descrição, quando conseguem ler.

Estabelece ainda, que as expressões "pode conter soja transgênica" e "pode conter ingrediente produzido a partir de soja transgênica" deverão constar do rótulo, independentemente do percentual da presença de soja transgênica, exceto se a soja ou ingrediente a partir dela produzido seja oriundo de região excluída pelo Ministério da Agricultura, Pecuária e Abastecimento (MAPA) do regime da Medida Provisória (MP) número 113, de 26 de março de 2003, ou de produtores e fornecedores de soja que obtenham a certificação estabelecida por essa mesma MP. Além destas informações, produtos transgênicos também devem conter em seu rótulo um selo amarelo, em forma de triangulo, com a letra $\mathrm{T}$.

A rotulagem de alimentos que contém organismos geneticamente modificados é ainda um desafio a ser implementado de forma ampla no Brasil. As empresas são obrigadas a fornecer esta informação, mas, a falta de fiscalização somada a informações mascaradas ou mesmo de maneira que dificulta a visualização imediata, fazem com que o "jeitinho" de burlar a lei, funcione. Por outro lado a vigilância sanitária, quase que de maneira generalizada, desenvolve uma verdadeira perseguição aos produtos da agricultura familiar camponesa, com punições severas e proibições de toda a ordem.

Diante disso, deixamos o questionamento: o que o Estado tem desenvolvido de políticas públicas, mesmo de fiscalização e apoio, aos produtos verdadeiramente saudáveis e livres de agrotóxicos e de transgênicos? Como tem agido frente aos crimes de contrabando de milhares de toneladas de agrotóxicos vindos ao Brasil, da Argentina e Paraguai? Como tem feito o controle da rotulagem dos transgênicos? Que pesquisas tem desenvolvido ou apoiado em vista de verificar os danos à saúde diante da contaminação dos transgênicos e do uso de agrotóxicos?

\section{Algumas Considerações}

No século XXI, com todas as evoluções em todos os campos imagináveis, desde a engenharia genética à medicina, vivenciamos ainda constantes preocupações com algo tão básico como a alimentação da população. Enquanto nos Estados Unidos a população sofre as consequências de uma "superalimentação" em quantidade, mas pobre em nutrientes, as pessoas 
dos países do continente africano padecem devido à desnutrição e falta de alimentos e água potável, sem falar da má qualidade de vida de modo geral.

A fome da África tornou-se então um pretexto para as mudanças que começaram a ocorrer na forma de produção de alimentos e assim foi implementada a revolução verde, sendo que nos dias atuais, há defensores de uma revolução duplamente verde, segundo Conway (2003), visto que a primeira não teria alcançado os seus objetivos. Desde então se passou a priorizar ainda mais a produtividade ao invés da qualidade, e, o maior exemplo disso são os transgênicos, sendo que neste sistema agrícola, os agrotóxicos tornaram-se indispensáveis, usados cada vez mais em maior quantidade. Vinculado a este "modelo" de produção, o Brasil tornou-se, o líder mundial no consumo de agrotóxicos do ano de $2008 \mathrm{em}$ diante, sendo que nos últimos dez anos o mercado mundial de agrotóxicos cresceu 93\%, mas, no Brasil esse crescimento alcançou 190\% segundo a Associação Brasileira de Saúde Coletiva (ABRASCO, 2012).

De acordo com Grisólia (2005) os cultivares transgênicos são os grandes responsáveis por esses números exorbitantes, e neste momento, $71 \%$ dos transgênicos são resistentes aos herbicidas, $28 \%$ são resistentes ao ataque de insetos e $1 \%$ possuem ambas as características. A manipulação do DNA das plantas transgênicas induz a mutações celulares e estresse metabólico, com alterações nos padrões fisiológicos e bioquímicos, não descartando ser essa manipulação a responsável pelo grande aumento na concentração de toxinas que causam alergias diversas.

Apesar do acesso aos alimentos ser ainda uma das grandes preocupações mundiais, não podemos deixar de pensar e analisar essa questão sob o olhar nutricional. Uma questão importante a compreender é que alimentação é muito mais do que apenas saciar a fome. A alimentação engloba a questão nutricional, mediante fonte de vitaminas e minerais essenciais ao funcionamento, manutenção e equilíbrio metabólico, sendo que a carência destes provoca mal prognóstico sobre a saúde. Deste modo, os alimentos devem ser de qualidade e estarem íntegros, sem vestígios de contaminação, seja por fungos, bactérias ou de resíduos químicos tão perigosos como os agrotóxicos, visto que além dos perigos de intoxicações, cânceres, doenças de pele, teratogênes $^{3}$ desregulação endócrina, efeitos na reprodução humana, neurotoxicidade, alterações negativas do sistema imunológico (BRITO, GOMIDE, CÂMARA, 2009). Os alimentos fazem parte de culturas, de costumes e tradições ao longo dos tempos e, por esse motivo as mudanças nos modelos de produção, que acontecem em curto espaço de tempo, em uma geração, podem

\footnotetext{
${ }^{3}$ Tudo o que pode produzir dano ao embrião ou feto durante a gravidez.
} 
causar verdadeiros desastres do ponto de vista de perdas em todos os sentidos; de outro modo se "ganhou" híbridos mais resistentes e transgênicos com características projetadas e alteradas.

Segundo a Abrasco (2012), cerca de 1/3 dos alimentos que os brasileiros consomem diariamente está contaminado com algum tipo de agrotóxico. Essa contaminação vai desde ingredientes ativos que são proibidos no país, a agrotóxicos não autorizados para aquele cultivo específico ou que estejam em concentrações que ultrapassem os limites máximos de resíduos considerados aceitáveis. As hortaliças e frutas são as grandes líderes desse indesejável ranking, sendo o pimentão o alimento de maior grau de contaminação, e em seguida o morango, pepino e entre outros conforme dados da ANVISA de 2011. Mas, não dá para se iludir que as hortaliças levam o maior volume de agrotóxicos, pois, pela extensão da plantação no Brasil, o soja ${ }^{4}$ e o milho são as campeãs no consumo.

Esses índices, em nossa compreensão são alarmantes, e, ao que parece, a tendência é de que num cenário bem próximo, a situação piore ainda mais se não houver medidas responsáveis. Apesar da comprovação científica da carcinogenicidade e do poder alergênico que os ingredientes ativos desses agrotóxicos consumidos pelas pessoas, seja nos alimentos, inalados na respiração ou na água cotidianamente, o Estado pouco tem feito seu papel de investigar e punir empresas e corporações que continuam lucrando muito com "este mercado". Enquanto o capital persegue sua busca desenfreada, enriquecendo algumas poucas pessoas a custa do adoecimento e morte de milhares, a situação parece continuar neste mesmo cenário.

Ploeg (2008), um estudioso dos impérios alimentares no mundo, destaca que os alimentos são cada vez mais projetados, sendo que a atual industrialização, produção e consumo são impulsionados por uma agenda bem definida, balizada pela "globalização, liberalização e distribuição de OGM's". De outro modo, aponta que as pesquisas mostram a existência de uma grande insegurança alimentar com relação ao volume necessário para alimentar os sete bilhões de pessoas do planeta. Contraditoriamente o Brasil incentiva com recursos financeiros e faz turbinar os dados apresentados pelo agronegócio em nome da "produção de alimentos", que não passam de commodities, e, no ano de 2012 cria a PNAPO, que por sua vez dela deriva, o Plano Nacional de Agroecologia e Produção Orgânica (PLANAPO) também destinando recursos, pela primeira vez na história. O desafio é fazer cumprir e acessar tais políticas além de garantir que se possa

\footnotetext{
${ }^{4}$ De acordo com Guanziroli e Berenger (2010), o Brasil só perde para os EUA em extensão da produção transgênica de soja, e, atualmente ultrapassa a 30 milhões e hectares cultivados por ano.
} 
fazer produção agroecológica em um ambiente não contaminado por agrotóxicos.

Diante deste quadro, é urgente e necessário o incentivo com investimentos públicos na produção ecológica, assim como as medidas de organização desta produção em cooperativas ou associações para que as pessoas da cidade e de todos os lugares tenham acesso a ela. Não há como desvincular a qualidade da alimentação com a qualidade de vida das pessoas, do ambiente e também da forma de trabalho. Os dados da obesidade e da desnutrição da população brasileira deveriam ser levados em conta com relação aos gastos públicos em saúde, pois eles apontam um sério problema. Tais dados são elevados e isto é sinal de que a qualidade a alimentação está mal o, que por outro lado, em nosso entendimento é uma amostra que o sistema de produção precisa ser repensado e reestruturado. Para tanto, é necessário inverter a lógica estatal, ao menos, frente aos investimentos em tecnologias, pesquisa e assistência técnica, de modo a visar a agroecologia.

\section{REFERÊNCIAS}

ASSOCIAÇÃO NACIONAL DE AGROECOLOGIA. Disponível em: http://abaagroecologia.org.br/wordpress/?page id=44. Acesso em 22 abr. 2014.

ABRASCO; Dossiê ABRASCO: um alerta sobre os impactos dos agrotóxicos na saúde. Abrasco: Rio de Janeiro, 2012.

ANDRIOLI, Antônio Inácio; FUCHS, Richard. Transgênicos: as sementes do mal. A silenciosa contaminação de solos e alimentos. São Paulo: Expressão Popular, 2008.

BRASIL. Decreto $\mathbf{2 4 6 8 0}$ de 24 de abril de 2003. Disponível em: http://www.planalto.gov.br/ccivil_03/decreto/2003/d4680.htm>. Acesso em: 10 jul. 2013.

BRASIL. LEI No 10.831, DE 23 de dezembro de 2003. Disponível em:> http://www.planalto.gov.br/ccivil_03/leis/2003/110.831.htm.< Acesso em: 10 jul. 2013.

BRITO, Paula Fernandes de; GOMIDE, Márcia; CÂMARA, Volney de Magalhães. Agrotóxicos e saúde: realidade e desafios para mudança de práticas na agricultura. Physis, vol.19 n.1, Rio de Janeiro, 2009. Disponível em:> http://www.scielo.br/scielo.php?script=sci_arttext\&pid=S010373312009000100011> Acesso em: 23 abr. 2014.

CAPORAL, Francisco Roberto; COSTABEBER, José Antônio. Agroecologia: alguns conceitos e princípios. Brasília: MDA/SAF/DATER-IICA, 2004. Disponível em:< http://agroeco.org/socla/wp-content/uploads/2013/11/Agroecologia-Conceitos-e-princpios1.pdf> Acesso em: 28, abr. 2014. 
CARNEIRO, Maria José. De "produtor" a "consumidor": mudanças sociais e hábitos alimentares. In: NEVES, D. P. (Org.). Processos de constituição e reprodução do campesinato no Brasil. Formas dirigidas de constituição do campesinato. Vol II. São Paulo: Unesp e Nead, 2009. p. 151-172.

CONTE, Isaura Isabel. Agricultura familiar e camponesa e a agroecologia. In: CAMP. Caderno de educação popular e direitos humanos. Porto Alegre: Camp, 2013. p. 55-58.

CONWAY, Gordon. Produção de alimentos no século XXI. Biotecnologia e meio ambiente. Tradução de Celso Mauro Paciornik. São Paulo: Estação Liberdade, 2003.

FREIRE, Paulo. Pedagogia do Oprimido. 32. ed. Rio de Janeiro: Paz e Terra, 1987.

FUCK, Marcos Paulo; BONACELLI, Maria Beatriz. Sementes geneticamente modificadas: (in)segurança e racionalidade na adoção de transgênicos no Brasil e na Argentina. Revista CTS, $\mathrm{n}^{\mathrm{o}}$ 12, vol. 4, Abril de 2009.

GALEANO, Eduardo. As veias abertas da América Latina. Tradução de Galeano de Freitas. 33. ed. São Paulo: Paz e Terra, 1991.

GRISÓLIA, Cesar Koppe. Agrotóxicos: mutações, câncer e reprodução. Brasília: UnB- DF, 2005.

GUERRANTE, Rafaela Di Sabato. Transgênicos: Uma visão estratégica. Rio de Janeiro: Interciência, 2003.

GUANZIROLI, Carlos; Marco Ortega BERNGER. Experiências bem - sucedidas em agronegócio no Brasil e desenvolvimento sustentável. Brasília: IICA, 2010.

LEAL, Marco Antonio de A; GUERRA, José Guilherme M; PEIXOTO, Ricardo TG; ALMEIDA, Dejair de. Utilização de compostos orgânicos como substratos na produção de mudas de hortaliças. Horticultura Brasileira, 2007.

LIMA, Elinete Eliete de; SOUSA, Anete Araújo de. Alimentos orgânicos na produção de refeições escolares: limites e possibilidades em uma escola pública em Florianópolis. Campinas: Revista de Nutrição, n. 24, v. 2, 2011.

MAESTRI, Mário Filho. Uma história do Rio Grande do Sul. 2. ed. Passo Fundo: UPF, 2000.

MAGALHÃES, Hilton M. Farmacologia Veterinária: Temas Escolhidos. Guaíba: Agropecuária, 1998. 
MELO, Hildete Pereira; SABBATO, Alberto Di. Gênero e trabalho rural. In: BUTTO, Andrea (Org). Estatísticas rurais e a economia feminista. Um olhar sobre o trabalho das mulheres. Brasília: MDA, 2009. p. 32-121.

MENACHE, Renata; MARQUES, Flávia. C.; ZANETTI, Cândida. “Autoconsumo e segurança alimentar: a agricultura familiar a partir dos saberes e práticas da alimentação". Revista Nutrição. V. 21. p. 145-158, 2008.

MINISTÉRIO DO DESENVOLVOLVIMENTO AGRÁRIO. Agricultura familiar no Brasil e o censo agropecuário de 2006. Brasília: MDA, 2009.

PLOEG, Jan. Douwe. Van Der. Camponeses e impérios alimentares: lutas por autonomia e sustentabilidade na era da globalização. Tradução de Rita Pereira. Porto Alegre: Ufrgs, 2008.

POLÍTICA NACIONAL DE AGROECOLOGIA E PRODUÇÃO ORGÂNICA. Decreto n. 7.794, de 20 de agosto de 2012.

POLLAN, Michel. O dilema do onívoro: uma história natural de quatro refeições. Tradução de Cláudio Figueiredo. Rio de Janeiro: Intrínseca, 2007.

QUEIROZ, Maria Isaura de. Uma categoria rural esquecida (1963). In: WELCH, Clifford Andrew; MALAGODI, Edgard; CAVALCANTI, Josefa; WANDERLEY, Maria Nazareth (Orgs.). Camponeses brasileiros. Leituras e interpretações clássicas. São Paulo: Unesp e Nead, 2009. p. 57-72.

REDE ECOVIDA. Disponível em: 〈www.ecovida. org. br>. Acesso em: 30 dez. 2012.

RIBEIRO. Silvia. Camponeses, biodiversidade e novas formas de privatização. In: CARVALHO, H. M. de. Sementes: Patrimônio dos povos a serviço da humanidade. São Paulo: Expressão Popular, 2003. p.51-72.

RUBIO, Blanca. Explotados y excluídos. Los campesinos latinoamericanos en la fase agroexportadora neoliberal. México: Plaza y Valdez, 2001.

VELHO, Otávio Guilherme. Capitalismo autoritário e campesinato. um estudo comparativo a partir da fronteira em movimento. 2. ed. São Paulo e Rio de Janeiro: Difel, 1979. 